\title{
Broadcast Burning of Sagebrush in the Winter
}

\section{L.F. NEUENSCHWANDER}

\section{Abstract}

Sagebrush-grass vegetation occupies about 5.5 million hectares of Idaho rangelands. Rangeland productivity has decreased as presettlement sagebrush densities have increased. Prescribed burning of such rangeland has proven to be an efficient and economic tool to reclaim sagebrush-dominated areas, but firing techniques and weather prescriptions for fire use have not been developed. Feasibility of winter burning with snow or ice on the surface of the soil was tested with the following restrictions: (1) sagebrush was dense, with a canopy cover about $50 \%$, and (2) distance between plants cannot exceed $50 \%$ of their average height. With these restrictions, fire carried through sagebrush canopies when effective wind speed was above $8 \mathrm{~km} / \mathrm{hr}(5 \mathrm{mph})$ and winter ignition index was $Y_{1} \geq 29$. Under the above prescription, only small areas burned. Winter burning might be impractical in most areas because of imposed stand limitations and the low number of days with proper burning conditions. However, winter broadcast burning is possible, inexpensive, and completely safe when snow or ice is present, and requires no fire control preparation or mop-up.

Sagebrush-grass vegetation occupies about 5.5 million ha (13.7 million acres) of Idaho rangelands (U.S. Dep. Agr. Forest Service 1972). Sagebrush density during presettlement times was no doubt far less than today. Increase in sagebrush density is due partly to early practices of heavy and uncontrolled grazing. Range condition has deteriorated to a point where the land is producing far less than its potential forage (Pickford 1932; Tisdale et al. 1969). On some Idaho rangelands, big sagebrush (Artemisia tridentuta) has increased in size, density, and cover, resulting in almost impenetrable stands. Livestock movement is restricted, and yields of forage species are reduced (Blaisdell 1953; Pechanec et al. 1954; Moomaw 1957). In such areas, available forage is exceedingly low $(<113 \mathrm{~kg} / \mathrm{ha})$, and is of little value to ranchers. Therefore, reduction of big sagebrush cover is considered a desirable range improvement practice (Mueggler and Blaisdell 1958; Pechanec et al. 1965).

Although attempts to reclaim Idaho rangelands from sagebrush have been successful, present-day methods of control are expensive. Herbicide spraying has been the most effective and least expensive method of controlling sagebrush (Bohmont 1954; Hyder and Sneva 1956; Mueggler and Blaisdell 1958; Taha and Payne 1976). However, the federal government recently placed an unwritten moratorium on the use of herbicides on the public domain. Ranchers are faced with the inflated costs of labor, equipment, and materials associated with mechanical methods of control as plowing, chaining, railing,

\footnotetext{
The author is assistant professor, College of Forestry, Wildlife and Range Sciences, University of Idaho, Moscow

Research was supported by the "Short Term Applied Research Program of the State of Idaho" and the Forest, Wildlife and Range Experiment Station. Contribution No. 172. Rexarch was conducted as a cooperative agreement between the BLM and the University of ldaho.

Manuscript received November 8, 1978
}

Table 1. Sagebrush stand characteristics of the mean, range, and coefficient of variation (c.v.) is based from 250 samples.

\begin{tabular}{lrrrr}
\hline \hline Characteristic & \multicolumn{1}{c}{ Mean } & Minimum & Maximum & \multicolumn{1}{c}{ C.V. } \\
\hline Canopy cover (\%) & 68.0 & 50 & 90 & 19.7 \\
Density & & & & \\
$\quad$ (plants/ha) & 11907.0 & 6723 & 672334 & 141.9 \\
Biomass (g/plant) & 1580.0 & 56 & 9860 & 148.2 \\
Fuel moisture (\%) & 37.0 & 29 & 44 & 12.4 \\
Height (cm) & 105.0 & 54 & 173 & 52.6 \\
Basal diameter & & & & \\
$\quad(\mathrm{cm})$ & 3.6 & 1 & 15 & 62.2 \\
Distance between & & & & \\
$\quad$ plants (cm) & 22.8 & 1 & 150 & 121.6 \\
\hline
\end{tabular}

and rotobeating, which may have to be followed by drilling and broadcast reseeding. Because of the expense, these methods are not practical on rangelands unless they are subsidized by a federal agency or unless alteration of the habitat is required.

Burning has been studied by Blaisdell (1953), Pechanec et al. (1954), Blaisdell and Mueggler (1956), Mueggler and Blaisdell (1958), and Ralphs et al. (1975). Results from controlled burning were reported by Blaisdell (1953), Wright and Klemmedson (1965), Wright (1971), and Harniss and Murray (1973). In contrast to chemical and mechanical methods of control, prescribed burning has been shown to be both an efficient and economical tool (Pechanec et al. 1965; Ralphs et al. 1975).

Winter burning has not been previously reported in sagebrush-grass. When burning of sagebrush-grass is possible during the winter, the risk of fire escape is nonexistent, and fire line preparation and fire control costs can be eliminated. The primary objective of this study was to determine if and under what conditions sagebrush rangeland can be burned in the winter.

\section{Methods}

The study area was located in southeast Idaho near the PointSprings allotment of the Burley District of the Bureau of Land Management (BLM). Slope varies from 0 level to $60 \%$. Winter winds are predominately from the southwest.

Twenty-one stands of sagebrush were originally selected for burning, but due to abnormal weather conditions, only five were burned. Restrictions were placed upon stand selection: (1) the canopy cover of sagebrush was above $50 \%$, and (2) the distance between individual sagebrush plants was not more than $50 \%$ of their height. Before each ignition measurements of density, canopy cover, distance between plants, height, length of major axis, and basal diameter were taken in ten pre-burn transects. Biomass was calculated according to Brown (1976). Multiple regression models were constructed to predict burnable stands.

Within the five stands, 50 burns were conducted without fire lines under differing weather conditions during the winter when the soil surface was frozen or covered with snow. In 33 areas the fire carried a 


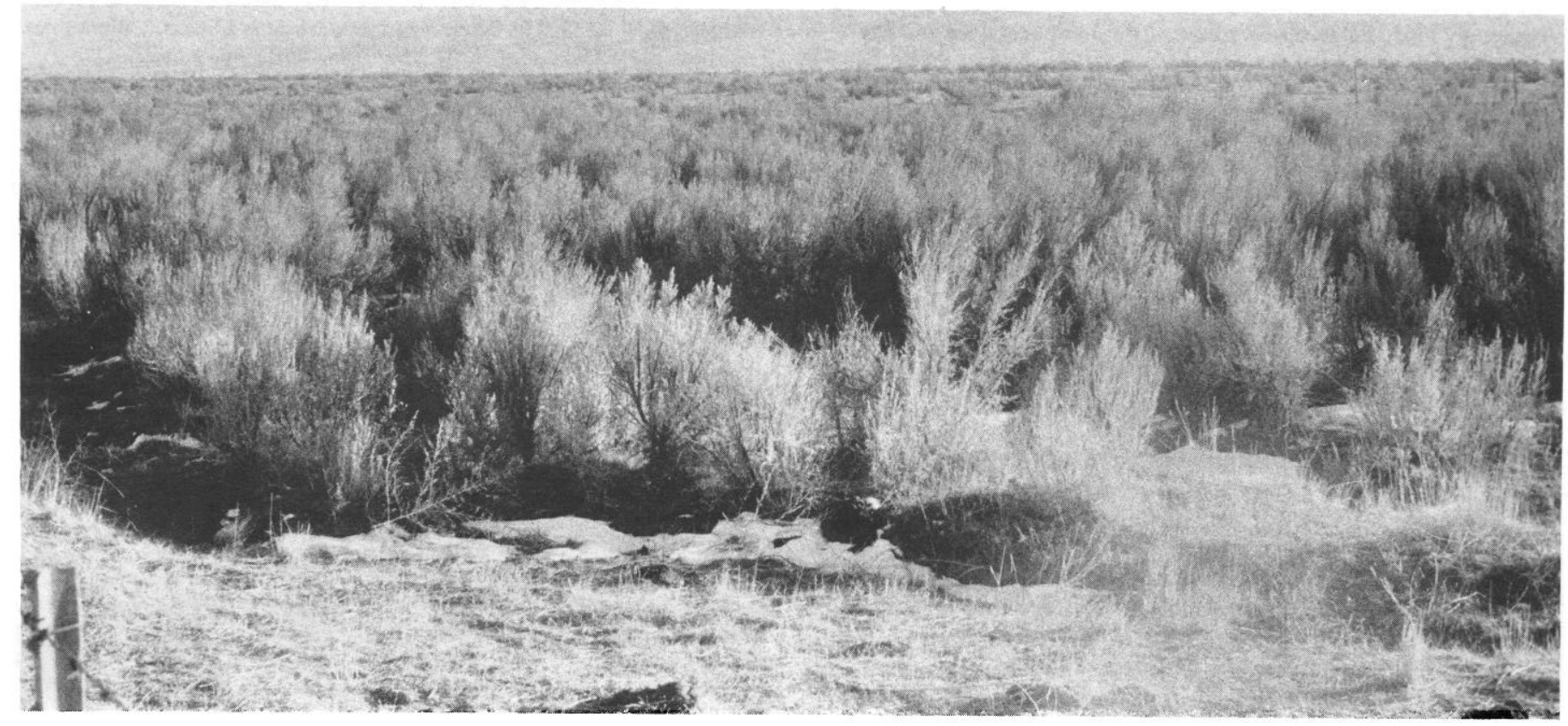

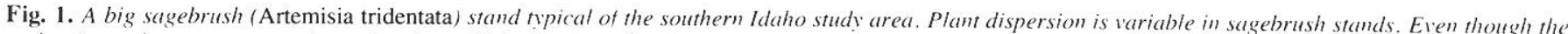
density and canopy cover of sagebrush are high, the irregular distances between plants restricted the fire spread.

minimum of $10 \mathrm{~m}$, and in 17 areas it did not. The forward rate of spread was measured by determining the time the fire took to travel 30 $\mathrm{m}$. All burns were small ( $\leq 0.25 \mathrm{ha}$ ) and fire control procedures were not necessary.

Data on temperature $\left({ }^{\circ} \mathrm{C}\right)$, effective wind speed $(\mathrm{km} / \mathrm{hr})($ Albini 1976), relative humidity (\%), and canopy fine fuel moisture (\%) were collected for each burn and were used as independent variables for multiple regression equations to build a winter ignition index and to predict the forward rate of fire spread. Weather conditions and stand comparing burned to unburned sites were tested with a grouped $t$-test.

\section{Results and Discussion}

Burning of big sagebrush (Artemisia tridentata ssp. tri(tentata. A. t. ssp. Wyomingensis and A.t. ssp. vaseyana) is feasible, because individual sagebrush plants easily burn. Single plants burned in the winter whenever canopy fuel moisture was below $37 \%$, air temperature exceeded $0^{\circ} \mathrm{C}\left(32^{\circ} \mathrm{F}\right)$, relative humidity was below $45 \%$, and the sky was clear. Combustion of the canopy was rapid under above conditions, but only fine fuels less than $0.64 \mathrm{~cm}(0.25 \mathrm{inch})$ in diameter burned. Larger stems charred but did not burn. Therefore, ignition of individual sagebrush plants could occur with snow or ice on the ground surface, but the fire would not spread to other plants except in limited cases.

Table 2. Comparison of average conditions in which fire did carry through a stand of sagebrush to those in which fire did not carry.

\begin{tabular}{lrrc}
\hline Conditions & Fire carried & $\begin{array}{c}\text { Fire did not } \\
\text { carry }\end{array}$ & $\chi^{\prime}$ \\
\hline Canopy cover $(\%)$ & \multicolumn{3}{c}{0.1} \\
Density (plants/ha) & $114,296.0$ & $121,020.0$ & 0.0006 \\
Biomass $(\mathrm{g} /$ plant $)$ & $1,634.0$ & $1,495.5$ & - \\
Height $(\mathrm{cm})$ & 103.8 & 108.3 & - \\
Basal diameter $(\mathrm{cm})$ & 3.8 & 3.2 & - \\
Distance between & 15.4 & 37.5 & 0.0067 \\
Temperature $\left({ }^{\circ} \mathrm{C}\right)$ & 9.0 & 9.0 & - \\
Relative humidity $(\%)$ & 49.3 & 46.6 & - \\
Effective wind $(\mathrm{km} / \mathrm{hr})$ & 8.3 & 6.6 & 0.0622 \\
Fuel moisture $(\%)$ & 37.0 & 38.0 & - \\
\hline
\end{tabular}

Signficance level $(\%)$ for differences between groups is determined by a grouped t-test.
Prerequisites to broadcast winter burning when snow or ice was on the ground were dictated by the structure of sagebrush stands. In order to burn, stands were of high density $(11,907$ plants/ha) and high canopy cover (68\%), and evenly distributed plants. These stand characteristics are atypical throughout most of the sagebrush areas in Idaho but occur in canyon and stream bottoms.

Restrictive fire-weather conditions further limited burning to late winter or early spring. General fire-weather guidelines for broadcast prescribed burning are a refinement of the fireweather conditions required for single plant ignition. Refinements include: temperature above $0^{\circ} \mathrm{C}\left(32^{\circ} \mathrm{F}\right)$ and below $7.2^{\circ} \mathrm{C}$ $\left(45^{\circ} \mathrm{F}\right)$; relative humidity less than $45 \%$; wind speed greater than $8 \mathrm{~km} / \mathrm{hr}(5 \mathrm{mph})$; canopy fine fuel moisture content less than $37 \%$; 3 days since last fog, rain, or snow; and clear skies. Burning outside of these guidelines produced consistent results; e.g., the fire usually did not spread.

When the temperature was below $0^{\circ} \mathrm{C}\left(32^{\circ} \mathrm{F}\right)$, the canopy of sagebrush was difficult to ignite, and the fire did not spread except in stands with dense canopies. When the temperature was above $7.2^{\circ} \mathrm{C}\left(45^{\circ} \mathrm{F}\right)$, melting snow and ice in the understory inhibited the rate and continuity of fire spread.

Relative humidity in southern Idaho in winter is seldom below $30 \%$. Within the burning conditions during this study, relative humidities ranged between 35 and $57 \%$. When the relative humidity was above $40 \%$, fire did not spread satisfactorily. Hence, burning in the winter required the lowest possible relative humidity.

Wind is the most important weather factor affecting fire spread through sagebrush canopies in the winter. With wind, fire carried freely in dense and continuous sagebrush canopies when temperatures and relative humidities were within the limits discussed above. However, fire did not carry without wind unless the slope was greater than $30 \%$. Albini (1976) combined slope and wind to form a fire spread factor called effective wind speed. An effective wind speed of about $8 \mathrm{~km} / \mathrm{hr}$ $(5 \mathrm{mph})$ is a threshold value below which the fire usually does not carry. Above this value the fire carries easily if canopy coverage is greater than $68 \%$. 
Table 3. Multiple regression for a winter ignition index, the rate of fire spread, and flame reach. Equations are based on 50 fires in 5 stands.'

$\begin{array}{ll}\text { Equation } & \text { Ignition Index } \\ \text { Eq. 1. } \quad Y_{1}=96.64-91.20\left(X_{1}\right)-1.1\left(X_{2}\right) ; R^{2}=0.811 \\ \text { where } Y_{1}=\text { ignition index, } \\ X_{1}=\text { fine fuel moisture content of the canopy }(\%), \\ X_{2}=\text { relative humidity }(\%) \\ \text { and } Y_{1}>0+ \\ \text { Eq. 2. Rate of Fire Spread } \\ \quad Y_{2}=81.60+19.20\left(X_{1}\right)-75.79\left(X_{2}\right)-0.99\left(X_{3}\right) ; R^{2}=0.874 \\ \text { where } Y_{2}=\text { predicted rate of fire spread }(\mathrm{m} / \mathrm{min}), \\ X_{1}=\text { effective wind speed }(\mathrm{m} / \mathrm{min}), \\ X_{2}=\text { fine fuel moisture content of the canopy }(\%), \\ X_{3}=\text { relative humidity }(\%),\end{array}$

Eq. 3. Flame Reach

$$
\begin{aligned}
Y_{3}=12.16-2.27\left(x_{1}\right)+4.29\left(X_{2}\right) ; R^{2}=0.36 \\
\text { where } Y_{3}=\text { flame reach }(\mathrm{m}+\mathrm{km} / \mathrm{hr}) \text { for winter burning } \\
X_{1}=\text { distance between plants }(\mathrm{m}), \\
\text { and } \quad Y_{3}>0 .
\end{aligned}
$$

\footnotetext{
' Due to a low sample number, regression equations should be used as general indicators and not as absolute prediction values.
}

Fuel moisture is obviously important in ignition of sagebrush canopies. The average fine fuel moisture was high $(37 \%)$ in sagebrush canopics at the time of the burn. However, leaves in the canopies are persistent and dessicate in the winter. Most the leaves of sagebrush are dry in the winter, but the twigs and stems are moist.

Fire carried through the canopies of sagebrush 3 days after the last period of moisture deposition when the skies were clear. Solar radiation evaporated moisture that condensed on the leaves at night. Even high cirrus clouds were enough to prevent evaporation from the leaf surfaces, inhibiting ignition of winter sagebrush canopies.

Fire carried through dense sagebrush canopies whenever the effective wind speed was greater than $8 \mathrm{~km} / \mathrm{hr}$ and the ignition index was greater than 29 . The ignition index can be determined by Equation 1 (Table 3 ). It is a combination of fine fuel moisture content and atmospheric moisture. Equation 1 predicts fire ignition based on the moisture parameters. Both fine fuel moisture content and relative humidity are negative in Equation $I$ because the higher the moisture content and relative humidity, the lower the probability of ignition. $Y$ must be greater than $O$ for the plants to ignite. When the ignition index was high and wind was present, under proper stand conditions, broadcast burning was possible in winter.

The rate of fire spread for winter burning can be predicted by Equation 2 (Table 3). $Y_{2}$ must be positive in order for the fire to spread. Since both fuel moisture and relative humidity, the major parameters that affect ignition of the canopy, are negative in Equation 2, they reduce the rate of fire spread. The two most important variables are effective wind speed and fine fuel moisture content. This is consistent with the theoretical fire spread model developed by Rothermal (1972).

Satisfactory results from winter broadcast burning were achieved when the burning index $\left(Y_{1}\right)$ was above 29 and the rate of spread $\left(Y_{.2}\right)$ was above $2 \mathrm{~m} / \mathrm{min}$. At a lower burning index and rate of spread, the fire usually did not carry.

Proper stand conditions are paramount for broadcast winter burning. Prediction of proper stand conditions is not solely a function of vegetative characteristics. Since variation within sagebrush stands is high, the resolution of site prediction is low.
The best prediction of stand conditions was based on the distance between plants and the effective wind speed, as shown in Equation 3 (Table 3). Basically, Equation 3 is flame reach and reads: "The farther apart the sagebrush plants, the more effective wind is needed to carry the fire." Without effective wind, the maximum distance the fire will carry between sagebrush plants is about $48 \mathrm{~cm}$. At winds of $8 \mathrm{~km} / \mathrm{hr}$, Equation 3 predicts that the fire will carry from 0.6 to $0.9 \mathrm{~m}$ and that the fire will carry $2.65 \mathrm{~m}(8.75 \mathrm{ft})$ with a $32 \mathrm{~km} / \mathrm{hr}(20 \mathrm{mph})$ effective wind speed.

Probably Equation 3 over-predicts the maximum distance between plants because: (1) it assumes a continuous, steady, up-slope wind; and (2) it assumes the convective winds created by the sagebrush plants have a negligible effect. Both assumptions are incorrect. Continuous upslope winds are common at high wind speeds, but at low speeds, winds are usually gusty and variable in direction. At high wind speeds, (e.g., winds $>30 \mathrm{mph}$ ) the fire may "blow itself out."

Fire creates convective winds over individual sagebrush plants that tilt the flames vertically. The degree of vertical tilting is proportional to the rate of combustion. Therefore, the vertical lifting effectively reduces the reach of the flames. Since flame contact between sagebrush plants is necessary for the fire to spread, and since the reach of the flames is reduced by these convective winds, the effective distance between individual plants is probably less than the predicted value.

\section{Conclusion}

Winter burning of individual sagebrush plants when snow and ice are on the ground is possible, but not practical. However, broadcast burning of sagebrush is not only possible, but also practical in very dense stands under restricted fireweather conditions. Many areas can be ignited in a short time, resulting in the creation of numerous openings in dense stands. The major benefit from winter burning is an increased edge effect, although areas previously dominated by sagebrush should produce increased forage as well. Adjacent unburned areas provide a reseeding source for forage plants.

Winter burning is completely safe and easy to apply. Environmental degradation does not occur. Fire sensitive plants are unharmed. Fire control lines and activities are not required. The difficulty with winter burning is not in controlling the fire, but rather in maintaining its spread. Once ignited and spreading, the fire will go out when the distance between plants or stand moisture increases, effective wind speed decreases, or changes in fuel types occur. Fire only proceeds upslope and with wind. Hence, winter broadcast burning might be impractical through most of the Great Basin because of imposed stand and fireweather limitations. However, winter burning in some stands is feasible.

\section{Literature Cited}

Albini, F.A. 1976. Estimating wildfire behavior. U.S. Dep. Agr. Forest Service. Gen. Tech. Rep. INT-30. Intermtn. Forest and Range Exp. Sta., Ogden, Utah. $91 \mathrm{p}$.

Blaisdell, J.P. 1953. Ecological effects of planned burning of sagebrushgrass range on the Upper Snake River Plains. U.S. Dep. Agr. Tech. Bull. 1075. Washington, D.C. 39 p.

Blaisdell, J.P., and W.F. Mueggler. 1956. Sprouting of bitterbrush ( $P$ urshia tridentata) following burning or top removal. Ecology 37:365-370.

Bohmont, D.W. 1954. Chemical sagebrush control-good and bad. Wyo. Agr. Exp. Sta. Circ. 54.7 p.

Brown, J.K. 1976. Estimating shrub biomass from basal stem diameters. Can. J. Forest Res. 153-158.

Harniss, R.O., and R.B. Murray. 1973. 30 years of vegetal change following 
burning of sagebrush-grass range. J. Range Manage. 26:322-325. Hyder, D.N., and F.A. Sneva. 1956. Herbage response to sagebrush spraying. J. Range Manage. 9:34-38.

Moomaw, J.C. 1957. Some effects of grazing and fire on vegetation in the Columbia Basin Region, Washington. Diss. Abstr. 17(4):733.

Mueggler, W.F., and J.P. Blaisdell, 1958. Effects on associated species of burning, rotoburning, spraying, and railing sagebrush. J. Range Manage. 11:61-66.

Pechanec, J.F., G. Stewart, and J.P. Blaisdell. 1954. Sagebrush burninggood or bad. U.S. Dep. Agr. Farmers' Bull. 1948. 34 p.

Pechanec, J.F., G. Stewart, and J.P. Blaisdell. 1965. Sagebrush control on rangelands. U.S. Dep. Agr. Agr. Handbook 277. Washington, D.C. 40 p.

Pickfor, G.D. 1932. The influcnce of continued heavy grazing and of promiscuous burning on spring-fall ranges in Utah. Ecology 13:159-171.

Ralphs, M., D. Schen, and F. Busby. 1975. Prescribed burning-effective control of sagebrush and open juniper. Utah Sci. 9:94-98.
Rothermal, R.C. 1972. A mathematical model for predicting fire spread in wildland fuels. U.S. Dep. Agr. Forest Service Res. Pap INT-1 15. Intermtn. Forest and Range Exp. Sta., Ogden, Utah. 40 p.

Taha, F.K., and G.F. Payne. 1976. Reinvasion of big sagebrush (Artemisia tridentata Nutt.) as affected by some treatments. In: Abstr. of Annu. Meet. Soc. Range Manage. Portland, Ore.

Tisdale, E.W., M. Hironaka, and M.A. Fosberg. 1969. The sagebrush region in Idaho, a problem in resource management. Univ. Idaho Agr. Exp. Sta. Bull. 512. 14 p.

U.S. Dep. Agr. Forest Service. 1972. The nation's range resources-a forest range environment study. Forest Resour. Rep. No. 19. Washington, D.C. $145 \mathrm{p}$.

Wright, H.A. 1971. Why squirreltail is more tolerant to burning than needleand-thread. J. Range Manage. 24:277-284.

Wright, H.A., and J.O. Klemmedson. 1965. Effects of fire on bunchgrasses of the sagebrush-grass region in southern Idaho. Ecology 46:680-688. 